\title{
The usefulness of left ventricular endomyocardial biopsy in clinical decision making in patients with unexplained heart failure
}

\author{
Adam Krajewski, Przemysław Trzeciak, Grzegorz Słonka, Alicja Nowowiejska-Wiewióra, Jacek Piegza, \\ Krzysztof Dyrbuś, Mariusz Gąsior \\ $3^{\text {rd }}$ Chair and Department of Cardiology, School of Medicine with the Division of Dentistry in Zabrze, Medical University of \\ Silesia in Katowice, Silesian Centre for Heart Diseases, Zabrze, Poland
}

Kardiochir Torakochir Pol 2019; 16 (4): 173-179

\begin{abstract}
Introduction: In recent years, the recommendations for an endomyocardial biopsy (EMB) were significantly extended. However, the proposed criteria are based on the consensus of experts and require further clinical trials.

Aim: To present the results of our diagnostic and therapeutic management based on left ventricular EMB (LV-EMB) in patients with unexplained heart failure (HF).

Material and methods: LV-EMBs were performed between August 2016 and March 2019. Bioptates analysis included histological, immunohistochemical and viral genome examinations. Patients meeting the inclusion criteria had additional immunosuppressive treatment.

Results: LV-EMBs were performed in 30 patients. The mean \pm SD age was $38.9 \pm 7.6$ years. About $75 \%$ of patients were in NYHA class III or IV, eight were in cardiogenic shock, and four required intra-aortic balloon pump support. Fourteen patients had myocarditis and four had a viral infection. In 9 patients, steroid therapy was implemented. During the mean \pm SD observational period of $10.5 \pm 8.1$ months, all patients survived, and 11 had an ejection fraction (EF) of over 35\%, of whom $6(66 \%)$ were on additional immunosuppressive therapy and 5 (24\%) on standard HF therapy ( $\mathrm{HR}=2.85$; $95 \% \mathrm{Cl}$ : 0.86-9.36; $p=0.08)$. An increase of $>20$ percentage points in the absolute EF was observed in 4 (44\%) patients on steroid therapy and $3(14 \%)$ on standard $\mathrm{HF}$ therapy $(\mathrm{HR}=2.32 ; 95 \% \mathrm{Cl}: 0.51-$ $10.39 ; p=0.27$ ).

Conclusions: An LV-EMB performed by skilled physicians is a safe procedure, verifies the cardiac magnetic resonance results, and allows the use of additional therapeutic options in patients with unexplained HF.
\end{abstract}

Key words: left ventricular biopsy, myocarditis, heart failure.

\section{Streszczenie}

Wprowadzenie: W ostatnich latach zalecenia dotyczące wykonywania biopsji mięśnia sercowego (EMB) zostały znacznie rozszerzone. Proponowane kryteria oparte są jednak na konsensusie ekspertów i wymagają dalszych badań klinicznych.

Cel: Przedstawienie wyników postępowania diagnostycznego i terapeutycznego opartego na biopsji lewej komory (LV-EMB) u pacjentów z niewyjaśnioną niewydolnością serca (HF).

Materiat i metody: Biopsje lewokomorowe (LV-EMB) wykonywano między sierpniem 2016 a marcem 2019 r. Analiza bioptatów obejmowała badania histologiczne, immunohistochemiczne i badania genomu wirusowego. Pacjenci spełniający kryteria włączenia mieli dodatkowe leczenie immunosupresyjne.

Wyniki: LV-EMB wykonano u 30 pacjentów. Średni wiek \pm SD wynosit 38,9 \pm 7,6 roku. Około $75 \%$ pacjentów było w III lub IV klasie wg NYHA, 8 we wstrząsie kardiogennym, a 4 wymagało zastosowania kontrapulsacji wewnątrzaortalnej. U 14 pacjentów stwierdzono zapalenie mięśnia sercowego, a u 4 infekcję wirusową. U 9 pacjentów wdrożono leczenie steroidami. Podczas średniego okresu obserwacji wynoszącego 10,5 $\pm 8,1$ miesiąca wszyscy pacjenci przeżyli, 11 pacjentów miało frakcję wyrzutową (EF) ponad 35\%, z czego 6 (66\%) stosowało dodatkową terapię immunosupresyjną, a 5 (24\%) standardową terapię HF $(\mathrm{HR}=2,85 ; 95 \% \mathrm{Cl}: 0,86-9,36 ; p=0,08)$. Wzrost frakcji wyrzutowej o ponad 20 punktów procentowych zaobserwowano u 4 (44\%) pacjentów leczonych steroidami i u 3 (14\%) leczonych standardową terapią $\mathrm{HF}(\mathrm{HR}=2,32 ; 95 \% \mathrm{Cl}: 0,51-10,39$; $p=0,27)$.

Wnioski: Biopsja lewokomorowa wykonywana przez wykwalifikowanych lekarzy jest bezpieczną procedurą, weryfikuje wyniki rezonansu magnetycznego serca i pozwala na zastosowanie dodatkowych opcji terapeutycznych u pacjentów z niewyjaśnioną HF.

Słowa kluczowe: biopsja lewokomorowa, zapalenie mięśnia sercowego, niewydolność serca.

Address for correspondence: Adam Krajewski MD, $3^{\text {rd }}$ Chair and Department of Cardiology, School of Medicine with the Division of Dentistry, Medical University of Silesia, Silesian Centre for Heart Diseases, 9 M. C. Skłodowskiej St, 41-800 Zabrze, Poland, e-mail: gorbachev@poczta.fm Received: 23.10.2019, accepted: 9.11.2019. 


\section{Introduction}

Endomyocardial biopsy (EMB) of the right ventricle (RV) and left ventricle (LV) was implemented into clinical practice in 1963 by Sekiguchi and Konno [1]. Over the years, this has become a technique of choice for diseases of the myocardium that can be observed at a tissue level and where no other diagnostic techniques can determine the cause of the disease. Moreover, histological and molecular diagnosis allows the administration of a therapy specific for myocardial disease [2]. Nevertheless, an EMB still remains controversial for some physicians due to the invasive nature of the procedure and the risk of complications [3].

The scientific statement from the American Heart Association, the American College of Cardiology, and the European Society of Cardiology published in 2007 defined the role of an EMB in the management of cardiovascular disease [4]. In the recent position statement of the European Society of Cardiology Working Group on Myocardial and Pericardial Diseases published in 2013, the recommendations for an EMB were significantly extended, including for patients with clinically suspected myocarditis, defined as the presence of $\geq 1$ clinical presentation (acute pseudoischemic pain, new-onset or signs of worsening heart failure (HF), arrhythmia symptoms, unexplained cardiogenic shock) and $\geq 1$ diagnostic criteria (new electrocardiogram, 24-hour Holter monitoring or stress test abnormalities; elevated troponin T/troponin I mass concentration, new abnormalities on cardiac imaging, changes in the muscle tissue in cardiac magnetic resonance (CMR) imaging in the absence of angiographically detectable coronary artery disease (CAD) and known pre-existing cardiovascular disease or extra-cardiac causes that could explain the syndrome [5]. This change broadened the potential number of patients requiring an EMB, especially with selective LV involvement in imaging examinations. However, the proposed criteria are based on the consensus of experts and require a critical approach until they are evaluated in subsequent registers and multicenter randomized trials.

The role of LV-EMB has increased in recent years. In spite of that, the number of EMBs performed in Poland is low. According to the data of the Association of Cardiovascular Interventions of the Polish Cardiac Society, 740 EMBs were performed in Poland in 2014 [6], mostly in patients after orthotopic heart transplantation $(\mathrm{OHT})$.

We observe an increasing number of patients admitted to hospitals due to HF of unknown etiology. Crucial for successful treatment is determining the etiology of the disease, especially in patients with suspected myocarditis or unknown cardiomyopathy. Therefore, since August 2016, in the $3^{\text {rd }}$ Department of Cardiology in Zabrze we have implemented a policy for patients with HF of unknown origin based on the outcomes of LV-EMBs.

\section{Aim}

The aim of the study was to present the results of our diagnostic and therapeutic management based on LV-EMB examinations in patients with unexplained HF.

\section{Material and methods}

Our study involved patients admitted to the hospital between August 2016 and March 2019 due to HF or cardiomyopathy of unknown etiology in whom an LV-EMB was performed.

All patients underwent a clinical examination, laboratory tests, a resting 12 -lead electrocardiogram, chest X-ray, Holter monitoring and 2-dimensional echocardiographic studies. Echocardiographic parameters were calculated and interpreted by an experienced operator according to established criteria. Cardiac magnetic resonance imaging was performed in patients without any contraindications with a 1.5 T scanner using a multi-channel body-array coil as a receiver. T1, T2 maps and late-gadolinium enhancement images were analyzed by an experienced operator, and the CMR findings were consistent with myocardial inflammation if at least two Lake Louise Consensus Criteria were present [7]. EMBs were only performed in patients without significant CAD and without severe valvular disease.

Significant CAD was defined as hemodynamically significant stenosis in the coronary arteries with a diameter $\geq 2.0 \mathrm{~mm}$. A $\geq 50 \%$ stenosis of the left main artery or the proximal segment of the left anterior descending artery and $a \geq 70 \%$ stenosis in other segments was considered as hemodynamically significant.

All patients were optimally treated, according to the current guidelines for heart failure. Stable patients were on standard pharmacological therapy. Inotropic agents, vasopressors and intra-aortic balloon pumps were given to patients with marked hypotension. The indications for an LV-EMB were unexplained HF with an LV ejection fraction $<35 \%$ and a) hemodynamic compromise or electrical instability of the heart; b) a recent worsening of heart failure symptoms (NYHA class II, III or IV) and no response to ordinary care within 2 weeks. Patients with a thrombus in the LV were excluded.

Before an EMB, every patient was treated with $75 \mathrm{mg}$ of aspirin. All EMBs were performed through the femoral artery. Upon the introduction of a $7 \mathrm{Fr}$ (Balton) sheath, every patient received a bolus of unfractionated heparin to achieve an activated clotting time of 200-250 s to prevent thromboembolism during the procedure. A 5 Fr pigtail catheter (Boston Scientific, USA) was then advanced into the left ventricle. After that, a long J-wire $(260 \mathrm{~cm}, 0.03500)$ was advanced over the pigtail catheter to hold the ventricular position, the pigtail was subsequently removed and an 8 Fr multipurpose guiding catheter (MB 2, $90 \mathrm{~cm}$, Launcher, Medtronic) was carefully advanced over the wire into the left ventricle [8]. The J-wire was removed and a $Y$ connector (Balton) was connected.

The optimal position and the distance between the guiding catheter tip and the lateral LV wall were checked in the left anterior oblique $20^{\circ}$ projection by injection of 5-6 $\mathrm{ml}$ of a contrast agent [8]. Using a Cordis $104 \mathrm{~cm}$ length bioptome (Cordis), 6-8 samples of 1-2 $\mathrm{mm}$ were taken during the procedure. To prevent an air embolism, the bioptome forceps were washed in saline before every insertion 
into the guiding catheter via the $Y$ connector. After completion of the procedure, the $7 \mathrm{Fr}$ sheath was removed and in the majority of patients, a vascular closure device was applied to achieve hemostasis.

Samples for histology and immunohistochemical analysis were fixed in $4 \%$ formalin and the bioptates for virus genome analysis were stored in RNAlater (Ambion, Foster City, CA, USA) tubes at room temperature. The material was analyzed at the Department of Molecular Pathology, University Hospital Tübingen, Germany. For histological examinations, $4-5 \mu \mathrm{m}$-thick sections of paraffin-embedded biopsies were prepared. Routine diagnostics included hematoxylin and eosin, Masson's trichrome and Giemsa staining. Histological examination assessed the presence of cardiomyocyte changes, scars, fibrosis, pathological vascular conditions, granulomas and inflammatory cell differentiation. The morphological criteria for myocarditis were based on the detection of inflammatory infiltrates and the presence of myocyte degeneration and necrosis according to Dallas criteria [9].

The histological analysis was supplemented by immunohistochemistry for the evaluation of an ongoing inflammatory reaction. Immunohistochemical diagnostics were based on the application of specific primary antibodies and secondary antibodies were conjugated with an enzyme complex (avidin-biotin-peroxidase complex; VectastainElite, ABC Kit, Vector Laboratories, Burlingame, CA, USA), producing a precipitating colored complex by using a staining solution [10]. Elevated inflammatory cell subsets and increased expression of adhesion molecules were detected using antibodies: CD3 for T-cells (Novocastra Laboratories, Newcastle, UK), CD68 for macrophages (DAKO, Glostrup, Denmark), and HLA-DR- (DAKO, Hamburg, Germany) to assess major histocompatibility complex class II expression in antigen-presenting immune cells [10]. Previously published criteria were used for the immunohistochemical diagnosis of myocardial inflammation [5, 10-12]. The presence of more than 14 leukocytes $/ \mathrm{mm}^{2}$ including $\geq 7$ cells $/ \mathrm{mm}^{2} \mathrm{CD}$ positive T-lymphocytes, CD68 positive macrophages and up-regulation of HLA class II was considered diagnostic for an abnormal inflammatory infiltrate, suggesting myocarditis [5]. The presence of myocyte necrosis with associated inflammatory infiltration based on an immunohistochemical assessment indicated acute myocarditis [12]. In the case of chronic myocarditis (formerly called borderline myocarditis), acute myocyte injury could not be found, but the extent of the inflammation and interstitial fibrosis was confirmed [12].

The molecular diagnostics were based on the detection, quantification and sequencing of viral genomes using methods which rely on polymerase chain reaction (PCR). DNA and RNA were extracted using proteinase-K digestion followed by extraction with phenol/chloroform. Enteroviruses (coxsackieviruses and echoviruses), parvovirus B19, Epstein-Barr virus, human herpesvirus type 6 and 7, cytomegalovirus, influenza virus $A$ and $B$, varicella-zoster virus and adenoviruses were evaluated by nested PCRs from
RNAlater-fixed endomyocardial biopsy samples, and RNA was transcribed into cDNA by reverse transcriptase according to the protocol of the manufacturer (AGS, Heidelberg, Germany) as described [10]. The enzymatic amplification of CDNA or DNA was performed as a nested PCR on a PerkinElmer GeneAmp PCR System 9600 (Applied Biosystems, Weiterstadt, Germany) in two 30-cycle programs [10]. Oligonucleotide sequences from the GAPDH gene were used as an indicator of correct isolation of the nucleic acids. Detection of the viral genome by PCR and specificity of all viral amplification products confirmed by automatic DNA sequencing were conditions for recognizing a viral infection [10].

Steroids were administered for patients with active myocarditis, without the presence of a virus, without acute myocyte injury, in the absence of clinical improvement or worsening despite typical HF treatment, with no contraindications for immunosuppression, when the minimum time from the onset of symptoms was 4 weeks or giant cell or eosinophilic myocarditis was found in hemodynamically unstable patients. The prednisone dose was $1 \mathrm{mg} / \mathrm{kg}$ daily (a maximum dose of $70 \mathrm{mg}$ ). After 4 weeks of treatment, the steroids were tapered each week by $5 \mathrm{mg}$ until the dose was $20 \mathrm{mg}$ /day. Immunosuppressive treatment was recommended for 3 months. Patients were further assessed during subsequent hospitalizations or outpatient visits.

The study was approved by the local institutional Ethics Committee and the patients gave their written informed consent.

\section{Statistical analysis}

Descriptive statistics were prepared based on patients' clinical characteristics, treatment, and the outcome information for registered patients. When normal distribution was observed, the results were presented as the mean \pm SD standard deviation. The median and interquartile range are applied in other cases. Categorical data are presented as frequency and proportion (\%). The differences between the groups were assessed with the $t$-test for normally distributed data, while the Mann-Whitney test was used for comparisons between non-normally distributed continuous variables and Fisher's exact test was used for categorical variables. Cox proportional hazards models were used to calculate the hazard ratios (HRs) and 95\% confidence intervals (Cls). A p-value of less than 0.05 was considered as significant. Statistical analyses were performed using the SPSS software package, v. 16.0.

\section{Results}

The baseline demographic and clinical characteristics of 30 patients in whom LV-EMB was performed are shown in Table I. The mean \pm SD age of patients was $38.9 \pm 7.6$ years and $83.3 \%$ of subjects were male. About $75 \%$ of patients were in NYHA functional class III or IV on admission, with 8 of them being in cardiogenic shock. Four patients required intra-aortic balloon pump support. The mean \pm SD LV ejection fraction was $19.6 \pm 7.1 \%$. CMR imaging was performed in 
Table I. Demographics and clinical characteristics of the study group

\begin{tabular}{|c|c|c|c|c|}
\hline Parameter & All & Myocarditis & DCM & P-value \\
\hline$N(\%)$ & $30(100)$ & $14(46.6)$ & $16(53.3)$ & \\
\hline \multicolumn{5}{|l|}{ Demographics: } \\
\hline Age [years] & $38.9 \pm 7.6$ & $37.3 \pm 8.8$ & $40.3 \pm 6.5$ & 0.57 \\
\hline Females, $n(\%)$ & $5(16.6)$ & $4(13.3)$ & $1(3.3)$ & 0.10 \\
\hline Growth $[\mathrm{cm}]$ & $177 \pm 8.9$ & $176 \pm 9.4$ & $177 \pm 8.6$ & 0.89 \\
\hline Weight [kg] & $81(73-89)$ & $78(72-82)$ & $86.5(74-117)$ & 0.0577 \\
\hline $\mathrm{BMI}\left[\mathrm{kg} / \mathrm{m}^{2}\right]$ & $26(23-28)$ & $24.5(23-26)$ & $27.5(25-33)$ & 0.03 \\
\hline \multicolumn{5}{|l|}{ Comorbidities and medical history, $n$ (\%): } \\
\hline Infection in the previous 3 months & $15(50.0)$ & $7(23.3)$ & $8(26.6)$ & 1 \\
\hline Atrial fibrillation/flutter & $6(20.0)$ & $0(0)$ & $6(20.0)$ & 0.0104 \\
\hline Chronic kidney disease (stage $\geq \mathrm{III}$ ) & $3(10.0)$ & $1(3.3)$ & $2(6.6)$ & 0.62 \\
\hline Peripheral artery disease & $0(0)$ & $0(0)$ & $0(0)$ & N/A \\
\hline Chronic obstructive pulmonary disease & $0(0)$ & $0(0)$ & $0(0)$ & N/A \\
\hline Hypercholesterolemia & $7(23.3)$ & $1(3.3)$ & $6(20)$ & 0.0498 \\
\hline Diabetes mellitus & $4(13.3)$ & $0(0)$ & $4(13.3)$ & 0.0445 \\
\hline Hypertension & $4(13.3)$ & $2(6.6)$ & $2(6.6)$ & 0.88 \\
\hline \multicolumn{5}{|l|}{ Clinical status on admission: } \\
\hline NYHA II, $n(\%)$ & $8(26.6)$ & $4(13.3)$ & $4(13.3)$ & 0.82 \\
\hline NYHA III, $n(\%)$ & $10(33.3)$ & $4(13.3)$ & $6(20)$ & 0.60 \\
\hline NYHA IV, $n(\%)$ & $12(40.0)$ & $6(20)$ & $6(20)$ & 0.76 \\
\hline Heart rate $[\mathrm{bpm}]$ & $78(68-98)$ & $76.5(61-105)$ & $78(69-98)$ & 0.98 \\
\hline Systolic blood pressure $[\mathrm{mm} \mathrm{Hg}]$ & $107.9 \pm 15.2$ & $102.4 \pm 14.0$ & $112.6 \pm 15.0$ & 0.065 \\
\hline Diastolic blood pressure [mm Hg] & $67.7 \pm 11.8$ & $62.4 \pm 8.0$ & $72.3 \pm 12.8$ & 0.0192 \\
\hline Pulmonary edema, $n$ (\%) & $2(6.6)$ & $0(0)$ & $2(6.6)$ & 0.17 \\
\hline Cardiogenic shock, $n(\%)$ & $8(26.6)$ & $6(20)$ & $2(6.6)$ & 0.060 \\
\hline Intra-aortic balloon pump, $n$ (\%) & $4(13.3)$ & $3(10)$ & $1(3.3)$ & 0.22 \\
\hline White blood cell count $[\times 1000 / \mu l]$ & $7.67(6.92-9.87)$ & $8.53(7.39-10.5)$ & $7.41(6.74-9.60)$ & 0.33 \\
\hline Hemoglobin [mmol/l] & $8.9 \pm 1.1$ & $8.47 \pm 1.1$ & $9.28 \pm 0.9$ & 0.0453 \\
\hline Bilirubin, median (IQR) $[\mu \mathrm{mol} / \mathrm{l}]$ & $16.2(7.6-22.1)$ & $22.2(9.62-28.6)$ & $9(6.05-17.2)$ & 0.00332 \\
\hline AST, median (IQR) [U/I] & $27(20-39)$ & $33(20-70)$ & $25(19-35)$ & 0.44 \\
\hline ALT, median (IQR) [U/II] & $43(28-86)$ & $51(22-158)$ & $40(28-75)$ & 0.57 \\
\hline C-reactive protein, median (IQR) [mg/l $]$ & $7.0(1.3-20.0)$ & $13.8(1.1-41.3)$ & $5.4(1.5-13.1)$ & 0.44 \\
\hline Creatinine level, median (IQR) [mmol/l] & $89.7(81-102)$ & $87.2(76.2-98.2)$ & $96.0(82.5-104.5)$ & 0.25 \\
\hline NT-pro BNP, median (IQR) [pg/ml] & $3010(1030-5496)$ & $2985(1644-5371)$ & $3452(1008-7554)$ & 0.91 \\
\hline Troponin, median (IQR) [ng/ml] & $0.022(0.013-0.081)$ & $0.022(0.011-0.094)$ & $0.021(0.016-0.067)$ & 0.75 \\
\hline CK-MB, median (IQR) [ng/ml] & $1.51(0.96-2.54)$ & $1.09(0.82-2.20)$ & $2.39(1.09-2.7)$ & 0.12 \\
\hline \multicolumn{5}{|l|}{ Echocardiographic assessment: } \\
\hline LVEF (\%) & $19.6 \pm 7.1$ & $20.6 \pm 8.0$ & $18.8 \pm 6.5$ & 0.49 \\
\hline$\underline{\operatorname{LVEDD}[\mathrm{mm}]}$ & $66.7 \pm 8.3$ & $65.2 \pm 9.9$ & $68 \pm 6.2$ & 0.38 \\
\hline LVESD [mm] & $57.8 \pm 9.7$ & $56.8 \pm 11.0$ & $58.6 \pm 8.8$ & 0.61 \\
\hline LVEDV [ml] & $237.5 \pm 75.1$ & $224.7 \pm 80.7$ & $248.7 \pm 70.6$ & 0.39 \\
\hline LVESV [ml] & $189.5 \pm 69.7$ & $178.8 \pm 76.8$ & $198.8 \pm 63.9$ & 0.44 \\
\hline$\underline{\mathrm{LA}}[\mathrm{mm}]$ & $47.7 \pm 7.0$ & $46.3 \pm 8.4$ & $48.8 \pm 5.7$ & 0.34 \\
\hline TAPSE $[\mathrm{mm}]$ & $17.1 \pm 3.8$ & $16.5 \pm 4.2$ & $17.6 \pm 3.5$ & 0.41 \\
\hline $\mathrm{RVSP}[\mathrm{mm} \mathrm{Hg}]$ & $33.3 \pm 9.37$ & $32.8 \pm 8.9$ & $33.7 \pm 10.0$ & 0.79 \\
\hline Pericardial fluid $>5 \mathrm{~mm}$ & $4(13.3)$ & $3(10)$ & $1(3.3)$ & 0.22 \\
\hline
\end{tabular}

Values presented as means \pm standard deviation, median (interquartile range) or number (percentage) of patients. AST - aspartate aminotransferase, ALT - alanine aminotransferase, BMI - body mass index, CK-MB - creatine kinase isoenzyme MB, IQR - interquartile range, LA - left atrium, LVEDD - left ventricle end-diastolic diameter, LVEDV - left ventricle end-diastolic volume, LVESD - left ventricle end-systolic diameter, LVESV - left ventricle end-systolic volume, LVEF - left ventricular ejection fraction, NT-proBNP - N-terminal pro-B-type natriuretic peptide, NYHA - New York Heart Association, RVSP - right ventricular systolic pressure, TAPSE tricuspid annular plane systolic excursion, N/A - not applicable. 
26 patients, and active myocarditis was present in 24 . There were no procedural complications during either coronarography or the LV-EMB. In 13 patients, coronarography was performed in other hospitals prior to admission to the Silesian Center for Heart Disease; therefore this examination was not repeated. Based on the histological and immunohistochemical criteria, myocarditis was confirmed in 14 patients. Four patients, including 3 with myocarditis, had evidence of a viral infection in their EMB (2 patients with both parvovirus B19 and human herpesvirus 6, 2 patients with only parvovirus $B 19)$. In the remaining 16 patients without myocarditis, dilated cardiomyopathy and interstitial fibrosis were found. All patients received standard treatment of heart failure. In 9 patients, steroid therapy was implemented. A cardioverterdefibrillator was implanted in 8 patients. Figure 1 shows the clinical management for patients according to the results of the biopsy. There were no deaths during hospitalization. The mean \pm SD period of hospitalization was $30.5 \pm 10.7$ days. During the mean \pm SD observational period of 10.5 \pm 8.1 months all patients survived, 11 patients had an LVEF of over $35 \%$, of which 6 (66\%) were on additional immunosuppressive therapy and 5 (24\%) on standard HF therapy. An increase of $>20$ percentage points in the absolute EF was observed in 7 patients; 4 (44\%) were on steroid therapy and $3(14 \%)$ on standard HF therapy. Table II presents the results stratified according to the confirmation of myocarditis and the applied treatment.

\section{Discussion}

An EMB provides a wide diagnostic spectrum of cardiac dysfunction at a cellular level but it is available only in a limited number of centers. Moreover, the number of procedures and the indications for an EMB differ even between experienced centers. In the Silesian Center for Heart Diseases in Zabrze, 483 EMBs were performed in 2017. From 1986 to 2017, 12,423 EMBs were performed in our center. The majority of these were performed in patients after an OHT, and less frequently in patients with myocarditis, cardiomyopathies [13] and structural heart diseases. All of these were RV-EMBs. The diagnostic value of an LV, versus an RV-EMB, has been assessed in various studies [12, 14]. Chimenti et al. compared the diagnostic accuracy of LV-EMBs and RV-EMBs in patients who had a biventricular

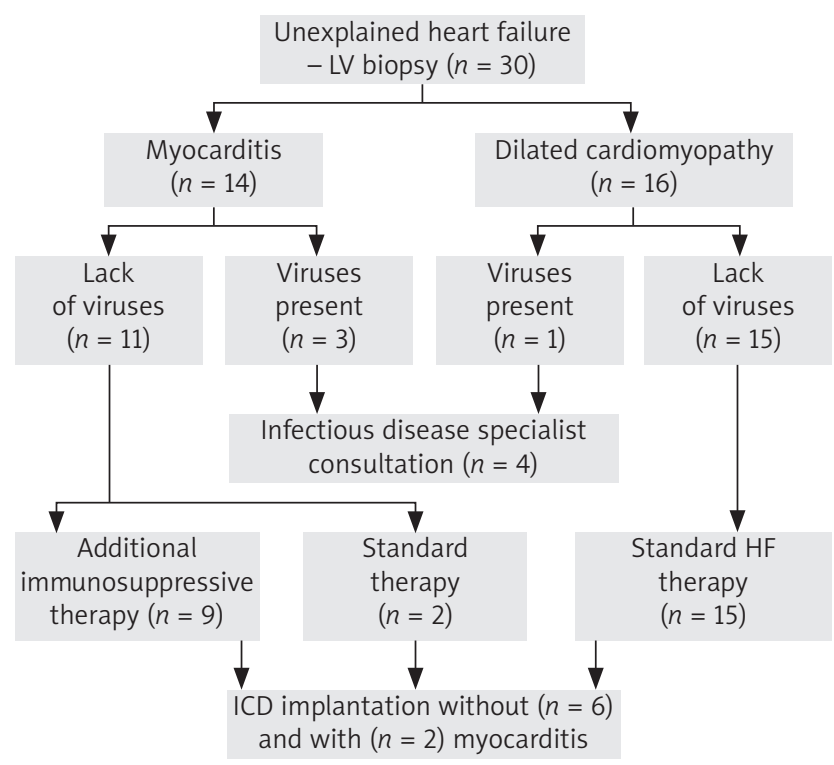

Figure 1. Clinical management of patients from the study group (number of patients in brackets)

(BV) EMB. The diagnostic yield of LV-EMBs was superior to RV-EMBs $(96.3 \%$ vs. $71.4 \%, p<0.001)$ [2]. Escher et al. compared the diagnostic value of LV versus RV-EMB specimens taken simultaneously in patients with suspected myocarditis. They demonstrated that LV-EMBs had a significant diagnostic advantage when interstitial fibrosis, cardiac remodeling, and hypertrophy were investigated. Pronounced or severe fibrosis in specimens from left and right ventricles was determined in $27.6 \%$ and $4.6 \%$ of patients, respectively. Morphological changes were found to be more reliably determined in LV-EMBs [14]. The presence of fibrosis in patients with dilated cardiomyopathy was associated with 2.43-fold higher odds of all-cause mortality and 3.22-fold higher odds of cardiovascular death or cardiac transplantation [15]. There are several studies reporting the benefits of BV-EMBs [2, 3, 12]. Yilmaz et al. demonstrated the diagnostic advantage of a BV-EMB compared to the selective univentricular procedure [3]. Stiermeier et al. assessed the diagnostic value of implementing a routine BV-EMB approach in 127 consecutive patients with suspected myocarditis. A BV-EMB provides better diagnostic performance

Table II. Results stratified according to confirmation of myocarditis and applied treatment

\begin{tabular}{|c|c|c|c|c|}
\hline Parameter & $\begin{array}{c}\text { DCM } \\
(n=16)\end{array}$ & $\begin{array}{l}\text { Myocarditis } \\
\quad(n=14)\end{array}$ & $\begin{array}{l}\text { Standard HF therapy } \\
\qquad(n=21)\end{array}$ & $\begin{array}{l}\text { Additional steroid therapy } \\
\qquad(n=9)\end{array}$ \\
\hline $\begin{array}{l}\text { LVEF > 35\% } \\
\mathrm{HR}, 95 \% \mathrm{Cl}\end{array}$ & $\begin{array}{c}4(0.25) \\
1\end{array}$ & $\begin{array}{c}7(0.50) \\
1.97(0.57-6.81) \\
p=0.28\end{array}$ & $\begin{array}{c}5(0.24) \\
1\end{array}$ & $\begin{array}{c}6(0.66) \\
2.85(0.86-9.36) \\
p=0.08\end{array}$ \\
\hline $\begin{array}{l}\text { Increase of > } 20 \text { percentage } \\
\text { points in the absolute EF } \\
\mathrm{HR}, 95 \% \mathrm{Cl}\end{array}$ & $\begin{array}{c}3(0.19) \\
1\end{array}$ & $\begin{array}{c}4(0.28) \\
1.19(0.26-5.42) \\
p=0.81\end{array}$ & $\begin{array}{c}3(0.14) \\
1\end{array}$ & $\begin{array}{c}4(0.44) \\
2.32(0.51-10.39) \\
p=0.27\end{array}$ \\
\hline $\begin{array}{l}\text { ICD implantation at any } \\
\text { time } \\
\mathrm{HR}, 95 \% \mathrm{Cl}\end{array}$ & $\begin{array}{c}9(0.56) \\
1\end{array}$ & $\begin{array}{c}6(0.43) \\
0.56(0.19-1.62) \\
p=0.56\end{array}$ & $\begin{array}{c}11(0.52) \\
1\end{array}$ & $\begin{array}{c}4(0.44) \\
0.60(0.18-1.9) \\
p=0.38\end{array}$ \\
\hline
\end{tabular}

Values presented as number (percentage) of patients. 
compared to a selective RV or LV-EMB. Moreover, a selective $\mathrm{LV}$-EMB was revealed to be superior to a selective RV-EMB for the confirmation or rejection of myocarditis [12].

The main reason for the low number of EMB procedures in the majority of centers is the fear of complications. In most previous studies, a low major complication rate for both LV- and RV-EMBs was reported. Some authors suggested a slightly superior safety profile for LV-EMBs [2, 3, $12,16]$. The overall complication rate varies from $1 \%$ up to $6 \%$ for centers taking samples mainly from the RV septum, including sometimes large numbers of repetitive EMBs in patients after an $\mathrm{OHT}$ [17]. In a report from a single-center study that involved 3,048 RV-EMBs, the risk of major complications including pericardial tamponade with pericardiocentesis, complete atrioventricular block with a permanent pacemaker, urgent cardiac surgery, advanced cardiac life support, hemothorax or pneumothorax was $0.12 \%$, and no deaths were reported [16]. A LV-EMB also seems to be safe. Chimenti et al. found for 3,068 patients who had RV-EMBs and 3,549 patients who had LV-EMBs between 1983 and 2010 that major complications appeared in only $0.45 \%$ and $0.36 \%$ of patients, respectively. A perforation with cardiac tamponade was noted in $3(0.08 \%)$ patients who had LVEMBs and in 9 (0.29\%) patients who underwent RV-EMBs. There was no death, permanent atrioventricular block or pulmonary embolization [2]. The experience of the physicians and the number of EMBs performed in the center play a crucial role in the low rate of complications. In Stiermeier et al.'s study, previous experience with the LV-EMB approach was the main reason for the low complication rate after implementation of the BV-EMB procedure [12]. Our 30 years of expertise in RV-EMBs contributed to avoiding major complications in the course of carrying out LV-EMBs, although the number of patients was limited.

Diagnosing myocarditis and determining the etiology of HF are often extremely challenging. Clinical symptoms, results of laboratory tests, electrocardiogram and echocardiography are often insufficient for establishing a proper diagnosis. Although CMR seemed to be a promising noninvasive approach, "real life" revealed the limitations of this method [18]. An endomyocardial biopsy is particularly worth considering in patients during the first weeks after the onset of the disease, especially in the cases of young people, and with those with severely worsening symptoms of HF. Based on the current clinical trials, there is no unambiguously established way to proceed in relation to the treatment directed to the causative agent, and in each situation, the risks and benefits of such treatment should be individually considered. The above work presents the possibilities and effects of using this type of treatment in our center. Analysis of the bioptates enables us to provide information about the presence of viral genomes, to differentiate between acute and chronic myocarditis and, consequently, to have an impact on therapeutic decisions [5, 19, 20]. Frustaci et al. demonstrated in 85 patients with myocarditis and chronic HF that inflammation recognized by immunohistology and the absence of viral genomes confirmed by poly- merase chain reaction allowed immunosuppression to be used, with a significant 6-month improvement in LV function [20]. This confirms the benefits of EMB as a diagnostic tool. Therefore, we commenced our program in close cooperation with the diagnostic center in Tübingen using their experience in this area. We obtained an immunohistological evaluation which was not only descriptive but also quantitative (number of cells $/ \mathrm{mm}^{2}$ ); therefore the results were unambiguous in terms of diagnosing inflammation and they also contained specific recommendations for further treatment (immunosuppression, antiviral, optimal HF therapy). In our study, $66 \%$ of patients with additional immunosuppressive therapy and $24 \%$ with standard HF therapy had an improvement in LVEF of over $35 \%(\mathrm{HR}=2.85$; $p=0.08)$. Currently, immunosuppression may be considered, on an individual basis, for infection-negative lymphocytic myocarditis, with no response to standard HF therapy, in patients with no contraindications to immunosuppression [5].

The main findings of the present study can be summarized as follows. Firstly, we demonstrated the presence of myocarditis in about $46 \%$ of patients with unexplained $\mathrm{HF}$ with reduced $\mathrm{EF}$. This is a result comparable to previous data. Mavrogeni et al. reported that $48 \%$ of patients with the diagnostic criteria for clinically suspected myocarditis had positive immunohistological criteria in an EMB [21]. Secondly, only $13.3 \%$ of our patients had the presence of the viral genome confirmed. A similar result was observed in another study in patients with dilated cardiomyopathy [22]. In contrast, Kühl et al. revealed the detection of viral genomes in $67 \%$ of patients clinically presenting with "idiopathic" dilated cardiomyopathy (DCM) [23]. Finally, the exclusion of viral persistence enables the implementation of immunosuppressive therapy, and this is one of the main advantages of biopsy over cardiac magnetic resonance [5]. In this way, a left ventricular endomyocardial biopsy changed the therapeutic management in $30 \%$ of our patients. EMBs should be considered in the diagnosis of patients with suspected myocarditis as the only method that identifies the etiology, the type of inflammatory infiltrates and the duration of inflammation which is associated with different prognoses and treatments [5, 20]. Confirmation of the active inflammatory process in the myocardium is one of the factors that should be taken into account when deciding the most appropriate time to implant a cardioverterdefibrillator. The correct diagnosis allows the implementation of adequate, targeted treatment, which is often the only chance to avoid severe chronic heart failure.

The major limitation is the low number of enrolled patients. Patients involved in the analysis were relatively young with a low number of comorbidities and may not correspond to the entire population of patients with HF of unknown etiology.

\section{Conclusions}

An LV-EMB performed by skilled physicians in an experienced center is a safe procedure. If the diagnostic tools are provided, it may be crucial for determining the origin of HF. 
An LV-EMB verifies the cardiac magnetic resonance results, and, as the diagnostic gold standard, it reduces the total diagnostic time and allows the use of additional therapeutic options in a large group of patients with severe impairment of LV systolic function.

\section{Acknowledgments}

This work was supported by the grants from the Medical University of Silesia KNW-1-183/N/6/K.

\section{Disclosure}

The authors report no conflict of interest.

\section{References}

1. Sekiguchi M, Konno S. Diagnosis and classification of primary myocardial disease with the aid of endomyocardial biopsy. Jpn Circ J 1971; 35: 737-754.

2. Chimenti C, Frustaci A. Contribution and risks of left ventricular endomyocardial biopsy in patients with cardiomyopathies: a retrospective study over a 28-year period. Circulation 2013; 128: 1531-1541.

3. Yilmaz A, Kindermann I, Kindermann M, Mahfoud F, Ukena C, Athanasiadis A Hill S, Mahrholdt H, Voehringer M, Schieber M, Klingel K, Kandolf R, Böhm M, Comparative evaluation of left and right ventricular endomyocardial biopsy: differences in complication rate and diagnostic performance. Circulation 2010; 122: 900-909.

4. Cooper LT, Baughman KL, Feldman AM, Frustaci A, Jessup M, Kuhl U, Levine GN, Narula J, Starling RC, Towbin J, Virmani R; American Heart Association; American College of Cardiology; European Society of Cardiology; Heart Failure Society of America; Heart Failure Association of the European Society of Cardiology. The role of endomyocardial biopsy in the management of cardiovascular disease: a scientific statement from the American Heart Association, the American College of Cardiology, and the European Society of Cardiology. Endorsed by the Heart Failure Society of America and the Heart Failure Association of the European Society of Cardiology. J Am Coll Cardiol 2007; 50: 1914-1931.

5. Caforio AL, Pankuweit S, Arbustini E, Basso C, Gimeno-Blanes J, Felix SB, Fu M, Heliö T, Heymans S, Jahns R, Klingel K, Linhart A, Maisch B, McKenna W, Mogensen J, Pinto YM, Ristic A, Schultheiss HP, Seggewiss H, Tavazzi L, Thiene G, Yilmaz A, Charron P, Elliott PM; European Society of Cardiology Working Group on Myocardial and Pericardial Diseases. Current state of knowledge on aetiology, diagnosis, management, and therapy of myocarditis: a position statement of the European Society of Cardiology working group on myocardial and pericardial diseases. Eur Heart J 2013; 34: 2636-2648, 2648a-2648d.

6. Ochała A, Siudak Z, Legutko J, Parma R, Chmielak Z, Bartuś S, Dobrzycki S, Grygier M, Moszura T, Pawłowski T, Dudek D. Percutaneous interventions in cardiology in Poland in the year 2014. Summary report of the Association of Cardiovascular Interventions of the Polish Cardiac Society AISN PTK. Adv Interv Cardiol 2015; 11: 177-181.

7. Friedrich MG, Sechtem U, Schulz-Menger J, Holmvang G, Alakija P, Cooper LT, White JA, Abdel-Aty H, Gutberlet M, Prasad S, Aletras A, Laissy JP, Paterson I, Filipchuk NG, Kumar A, Pauschinger M, Liu P; International Consensus Group on Cardiovascular Magnetic Resonance in Myocarditis. Cardiovascular mag netic resonance in myocarditis: A JACC White Paper. J Am Coll Cardiol 2009; 53: 1475-1487.

8. Kherad B, Köhncke C, Spillmann F, Post H, Noutsias M, Pieske B, Krackhardt F, Tschöpe C. Postprocedural radial artery occlusion rate using a sheathless guiding catheter for left ventricular endomyocardial biopsy performed by transradial approach. BMC Cardiovasc Disord 2016; 16: 253.
9. Aretz HT, Billingham ME, Edwards WD, Factor SM, Fallon JT, Fenoglio JJ Jr, Olsen EG, Schoen FJ. Myocarditis: a histopathologic definition and classification. Am J Cardiovasc Pathol 1985; 1: 3-14.

10. Kindermann I, Kindermann M, Kandolf R, Klingel K, Bültmann B, Müller T, Lindinger A, Böhm M. Predictors of outcome in patients with suspected myocarditis. Circulation 2008; 118: 639-648.

11. Richardson P, McKenna W, Bristow M, Maisch B, Mautner B, O'Connell J, Olsen E, Thiene G, Goodwin J, Gyarfas I, Martin I, Nordet P. Report of the 1995 World Health Organization/International Society and Federation of Cardiology Task Force on the Definition and Classification of Cardiomyopathies. Circulation 1996; 93: 841-842.

12. Stiermaier T, Föhrenbach F, Klingel K, Kandolf R, Boudriot $E$, Sandri $M$, Lin ke A, Rommel KP, Desch S, Schuler G, Thiele H, Lurz P. Biventricular endomyocardial biopsy in patients with suspected myocarditis: feasibility, complication rate and additional diagnostic value. Int J Cardiol 2017; 230: 364-370.

13. Wojnicz R, Nowak J, Szyguła-Jurkiewicz B. Adjunctive therapy with low-molecular-weight heparin in patients with chronic heart failure secondary to dilated cardiomyopathy: one-year follow-up results of the randomized trial. Am Heart J 2006; 152: 713. e1-7.

14. Escher F, Lassner D, Kuhl U, Gross U, Westemann D, Poller W, Skurk C, Weitmann K, Hoffmann W, Tschope C, Schultheiss HP. Analysis of endomyocardial biopsies in suspected myocarditis - diagnostic value of left versus right ventricular biopsy. Int J Cardiol 2014; 177: 76-78.

15. Gulati A, Jabbour A, Ismail TF, Guha K, Khwaja J, Raza S, Morarji K, Brown TD, Ismail NA, Dweck MR, Di Pietro E, Roughton M, Wage R, Daryani Y, O'Hanlon R, Sheppard MN, Alpendurada F, Lyon AR, Cook SA, Cowie MR, Assomull RG, Pennell DJ, Prasad SK. Association of fibrosis with mortality and sudden cardiac death in patients with nonischemic dilated cardiomyopathy. JAMA 2013; 309: 896-908.

16. Holzmann M, Nicko A, Kuhl U, Noutsias M, Poller W, Hoffmann W, Morguet A Witzenbicher B, Tschope C, Schultheiss HP, Pauschinger M. Complication rate of right ventricular endomyocardial biopsy via the femoral approach: a retrospective and prospective study analyzing 3048 diagnostic procedures over an 11-year period. Circulation 2008; 118: 1722-1728.

17. Deckers JW, Hare JM, Baughman KL. Complications of transvenous right ventricular endomyocardial biopsy in adult patients with cardiomyopathy: a seven-year survey of 546 consecutive diagnostic procedures in a tertiary referral center. J Am Coll Cardiol 1992; 19: 43-47.

18. Lurz P, Eitel I, Adam J, Steiner J, Grothoff M, Desch S, Fuernau G, de Waha S, Sareban M, Luecke C, Klingel K, Kandolf R, Schuler G, Gutberlet M, Thiele H. Diagnostic performance of CMR imaging compared with EMB in patients with suspected myocarditis. JACC Cardiovasc Imaging 2012; 5: 513-524.

19. Schultheiss HP, Kühl U, Cooper LT. The management of myocarditis. Eur Heart J 2011; 32: 2616-2625.

20. Frustaci A, Russo MA, Chimenti C. Randomized study on the efficacy of immunosuppressive therapy in patients with virus-negative inflammatory cardiomyopathy: the TIMIC study. Eur Heart J 2009; 30: 1995-2002.

21. Mavrogeni S, Spargias C, Bratis C, Kolovou G, Markussis V, Papadopoulou E, Constadoulakis P, Papadimitropoulos M, Douskou M, Pavlides G, Cokkinos D. Myocarditis as a precipitating factor for heart failure: evaluation and 1-yea follow-up using cardiovascular magnetic resonance and endomyocardial biopsy. Eur J Heart Fail 2011; 13: 830-837.

22. Pawlak A, Przybylski M, Mozenska O, Gil K. Frequency of viral nucleic acids detection using real-time PCR in endomyocardial biopsy samples, blood samples from the ventricle and peripheral blood in patients with dilated cardiomyopathy. Eur Heart J 2013; 34 (suppl 1): 511.

23. Kühl U, Pauschinger M, Noutsias M, Seeberg B, Bock T, Lassner D, Poller W, Kandolf R, Schultheiss HP. High prevalence of viral genomes and multiple viral infections in the myocardium of adults with "idiopathic" left ventricular dysfunction. Circulation 2005; 111: 887-893. 